\title{
Malgorzata Bieńkowska*
}

University of Bialystok

\section{TRANSSEXUAL MASCULINITY CONSTRUCTION IN POLAND ${ }^{1}$}

\begin{abstract}
The aim of this paper is to present how transmen perceive their masculinity while constructing it during the process of transition in Poland. One's own sexual identity can be demonstrated in various ways. However, transsexual people frequently follow stereotypical images of being a woman or a man. They seek a clear and obvious message so as to express themselves and their sex. It is related to forming their own image, appropriate body-language and their behavior towards the opposite sex. That is why transsexual people tend to choose sexually unambiguous clothing, avoiding unisex fashion.
\end{abstract}

Keywords: transgender/transsexuality, self-identity, transmen identity, queer theory

\section{TRANSMAN² - TRANSSEXUALITY DEFINING}

Raewyn Connell emphasizes how in contemporary western societies there are various forms of masculinity and femininity (2005: 141-142). She mentions three masculinity types: hegemonic, complicit and subordinate. These three analytical types are correlated with the relation between socially established sex hierarchy, dominance and submission structure (see Connell 2005: 79-80). While referring to transmen, however, it seems that the most classical type, the hegemonic one, is dominant ${ }^{3}$. This type is based on a patriarchal male model. Transmen, while trying to construct their way of expressing masculinity, tend to be based on the model most comprehensible to their environment. They prefer this type of masculinity, which gives them a certain sense of security as it does not evoke any doubts. When they construct themselves in this way, nobody doubts they are genuine men.

* Corresponding author: Małgorzata Bieńkowska, Instytut Socjologii, Uniwersytet w Białymstoku, plac Uniwersytecki 1, 15-420 Białystok; e-mail: m.bienkowska@uwb.edu.pl.

1 I use the term "transsexuality", as the people being the subject of my analysis described themselves using it. These were mainly the people who wanted physical reconstruction of their bodies. "Transgenderism" is the term that is apparently more politically correct but less likely to be used by my interviewees.

2 I mean $\mathrm{f} / \mathrm{m}$ transsexual people (born as women but feeling men).

3 This will be continued in the next part of my paper. 
Transsexuality is defined as a disease entity: gender dysphoria or gender identity dysphoria (GID). There are both GID diagnosis criteria and medical procedures towards people identifying as transwomen or transmen (see DSM-IV)

Medical discourse concerning transsexuality has strongly influenced the perception of this phenomenon. It has emphasized the necessity to transform the body, undergoing sex correction so that the body would reflect social perception of being a woman or a man. Medicine regards transsexuality as an illness, a gender dysphoria that can be treated by both hormone therapy and surgery. A transsexual person is one that does not identify with his or her sex and aims at adjusting the body to his or her mental identification. Authors of the Polish website devoted to transsexuality define the subject in the following way: "Transsexuality is a gender identity disorder in which a conflict exists between an individual's identification with a gender and their biological sex". The World Health Organization uses the International Statistical Classification of Diseases and Related Health Problems, in which transsexuality is recognized in this classification as a F64.0. Sexologists, while following the medical discourse mentioned above, define transsexuality according to the criteria of DSM-IV. There are two diagnostic categories mentioned:

1) "strong and permanent identification with the opposite sex, i.e. wishing or maintaining to be somebody of opposite sex",

2) "permanent discomfort or sense of inconsistency between one's identity and their assigned sex" (see Bancroft 2011: 303).

In the literature on the subject, transsexuality is defined as crossing sexual borders, with the emphasis on body correction. As psychologist, Alicja Strzelecka points out:

Transsexuality as a phenomenon is often used as proof that there is not a simple female/male dichotomy, that matters of sexual identity are much more complicated than they seem to be. Transsexual people are perceived as the ones breaking social taboos, transgressing borders of sex, opening new perspectives of understanding their sexuality to average men and women (2004: 481).

It needs to be mentioned that not all transsexual people pursue sex reassignment surgery; some of them do not need such radical interference in their body. However, British sociologist, Sally Hines, demonstrates a certain alternative in her definition of transsexuality, insisting that this term refers to people whose sex reassignment is obtained through hormones and/or surgical procedures (2008: 99).

Transsexuality, however, is not merely a medical phenomenon. Above all, it is a unique social phenomenon. There is a strong social dimension related to sex (gender); it means adjusting to social roles assigned to sex and presenting oneself in an appropriate and credible way. Ethnomethodologists focused on it, as Sally Hines emphasizes:

Ethnomethodological studies located gender within the social framework of everyday meaning and interpretation, to illustrate how "gender" is dependent upon subjective meaning and social

4 DSM-IV (Diagnostic and Statistical manual of mental Disorders) - mental disorders classification system of the American Psychiatric Association launched in 2000. 
construction. Yet ethnomethodology is problematic for a contemporary sociological understanding of transgender because of its reliance on a binary model of gender. Although the possibility of moving between the categories of gender is raised, it is only possible to move from female to male or from male to female within this analysis (Hines 2007: 15).

\section{METHODS AND SAMPLE}

Transexuality is a barely scientifically recognized phenomenon in Poland. Initially it was discussed among doctors specializing in this area. It was only during recent years when sociologists interested gender or queer studies began the analyses related to this subject. I will refer to the research on transsexuality that I did in Poland in 2002-2011. I conducted 23 interviews with transsexual people, including 13 interviews with $\mathrm{f} / \mathrm{m}$ transsexuals. The interviews were completed with data collected in Internet forums ${ }^{5}$ and websites for transgender people . $^{6}$

The aim of the research was to obtain wider knowledge concerning the transsexual minority in Poland. Transsexualism is a complex and multifaceted phenomenon related to matters of individual identity, sexual roles, stereotypes regarding interpersonal relations and, in a broader context, civil rights, minorities in a society, medical discourse, and legal regulations related to sex reassignment. In this paper I will solely focus on transmen (f-m), born with a body of a female but identifying as men considering their sexual identity. I want to focus on one segment of my research, demonstrating how transmen construct their male identity. While carrying out the research I assumed that transsexual people, particularly during the stage of transition and after this stage, prefer "blurred" sexual categories, not making them choose traditional sexual roles, consequently choosing "unisex style". This style intermingles female and male features, not being explicit, allowing achieving universal space.

In Poland transsexual people still face a legal situation that is not regulated by any legal act. The existing legal provisions enable them to change their birth certificate and allow sex reassignment but there is still no appropriate bill of regulating the issue of gender recognition comprehensively. The activists working for Trans-Fuzja Foundation Supporting Transgender People, Lalka Podobińska, Anna Grodzka and Wiktor Dynarski focus on these issues, emphasizing that transsexual people are not included in the legal system. They mention how people during the transition process are obliged to use identification documents with a photo not reflecting their current appearance. This situation contributes to difficult and humiliating events when the transsexual person is forced to explain the problem to a police officer or an official. This is only one of the legal problems transsexual people in Poland have to cope with (see Dynarski, Grodzka and Podobińska 2010; Bodnar 2010).

It needs to be emphasized that transsexual people tend to conceal their identity, particularly in small towns or villages, as they are perceived in a negative perspective, often being stigmatized. In Poland, the transsexual minority is a specific group, closed, suspicious, employing

\footnotetext{
5 I used generally accessible, open Internet forums.

6 The studies were more extensively presented in the book published in 2012 Transsexuality in Poland. Crossing binary sexual system in individual and social dimensions.
} 
self-stereotypes, and discriminated against. That is why contacting this group, getting through to particular individuals seemed to be the biggest obstacle. However, a conference on transsexuality organized by Alicja Kuczynska and her co-workers from the University of Wroclaw proved to be an ideal situation in helping establish contacts with transsexual people. During this conference I met a transsexual person who, after my speech, started a conversation with me. This was a valuable meeting since this person agreed to take part in the research as well as help me establish contacts with other transsexual people. It was an effective snowball method. The next step was to publicize the research and publish an appropriate advertisement on a website for transsexual people. As a result, several other people contacted me and declared their willingness to take part in the research.

Unfortunately, the free interview proved to be an insufficient form, making other people tell their stories according to the expected (in their opinion) scenario. There were stories of their childhood, their willingness to play games attributed to the opposite sex, the names they tended to use not being suitable for their metrical sex. It might raise doubts as to whether the method was appropriate and if the people interviewed were sincere. I do not presume any bad intentions my interviewees could have had. It was rather a matter of a certain safety mechanism I discovered while talking with a few transsexual people interested in my surveys. It was something I will call a certain mask, an official transsexual's mask. It is a kind of façade behind which the true, personal, memorable transsexual person's experience is hidden. Yet, these people are perfectly aware of the story that is expected from them, so they construct their narrative to fit the classical transsexual's profile. This mask is probably put on in order to convince the specialists (doctors, sexologists, psychiatrists, judges) that one is really a transsexual and deserves appropriate treatment and legal procedure. If one is aware of this trap, a free interview is a good scientific instrument.

Another significant matter while doing research concerning transsexual people is the researcher's openness, their ability not to judge the story and not to impose their own narrative. Jacob Hale made a list of 15 recommendations for a non-transsexual researcher investigating the subject, and stressed that transsexual people cannot be treated as experts in their own experience. Hale emphasizes respect towards the interlocutor along with a simultaneous critical analysis (see Hale 1997). Hale's guidelines seem to be obvious but one must be aware that they are the result of negative experience with researchers whose approach was unacceptable to transsexual people. Researchers should not behave as technocrats/colonizers who know better and tell a better story. It is worth emphasizing that the research on transsexuality used to be a part of a discourse on a certain deviance. This stance is unacceptable nowadays and it would not be appreciated by scientists.

During the later stage of the research I used secondary data analysis, mainly a collection of transsexual patients' letters collected by Kazimierz Imieliński and Stanisław Dulko in "Apokalipsa płci". Blogs written by transsexual people are also important and interesting material. They could be regarded as contemporary, specific memoirs. Another interesting source of information are entries in internet forums for transsexual people. These discussions take place on Transfuzja website, which focuses on support for transgender people (http://forum.transfuzja.org).

The content or discourse analysis was an auxiliary instrument complementing my research. 


\section{CONSTRUCTING CREATION ACCORDING TO SOCIAL EXPECTATIONS}

Gendering makes people recognize their own and other people's sex and gender. They establish appropriate interactions and apply proper behavior norms. They carry certain expectations related to socially accepted appearance and behavior features for women and men. Transsexual people undergo socialization in a specific way. First, they are socialized according to other people's perception of their sex, based on their registered sex. When they become aware of their own transsexuality they also begin internalizing the norms of the sex biologically opposite to their registrar sex, since this is the sex they identify with. Then, the process of acquisition of behavior patterns (both male and female) starts along with the process of adapting these patterns to one's own identification.

Being a man or a woman is closely related to a binary sex system within which the members of society are socialized from the very beginning. In this system "being a man" and "being a woman" seem to be two opposed, separate alternatives to locate people in a social space. Although research analyzing the phenomenon of sex distinguish "sex" and "gender", in popular perception these two categories are strongly identified with each other. In most societies one can be either a woman or a man. Consequently, a person with a body of a man is expected to perform social roles attributed to men (the same applies to people with a body of a woman; they are expected to be women in socio-cultural dimension).

Harold Garfinkel in his "Studies in Ethnomethodology" in analyzing the case of transsexual Agnes, insists that sex is a specific social obviousness. In popular perception, it is sex/ body that makes a person a woman or a man for all their life. It is invariable, it is obvious.

Body, being something external, visible and exposed in contemporary culture, becomes a significant (yet not the only) medium that defines who the person is. It is an important factor, according to which one can be defined and labeled, and so can be others. Michel Foucault, in Discipline and Punish: The Birth of the Prison, demonstrates inscribing a certain social message in the body, its taming, presenting a "political technology of body". He outlines the significance of the look through the panopticon metaphor. It refers to contemporary body discipline, where the body is exposed to continuous control, considering its appearance, its beauty. Foucault insists that when one stands in a visual field, they acquire everything brought by the field of thought (1993: 243).

Sex identity is this visual field. Self-definition that was acquired is something that is strongly submitted to social control. It is constantly confirmed by analyzing social feedback. It happens on the "looking glass self" level. Sex identity could be manifested in various ways, yet transsexuals frequently refer to stereotypical images concerning masculinity and femininity.

\section{SEX STEREOTYPES AND MASCULINITY/FEMININITY IMAGES AMONG TRANSSEXUAL PEOPLE}

Walter Lippmann formulated the notion of stereotype in 1922. According to him, a stereotype is a brief and emotional image of the world, including things, institutions and people 
(Lewandowski 1996: 88). In every society there is a set of common convictions concerning strangers, foreigners, others; this set is based on stereotypes, whether negative or positive.

Stereotypes are simplifications allowing people to treat certain groups of individuals, ignoring their real features, in a schematic way. When labelling people it seems easier to function in the world. Stereotypes form the basis for establishing conformist relations with other people. Ida Kurcz questions whether stereotypes are subjects to change and if they could be refuted. She argues it is not possible to disprove stereotypes, although they can be modified, e.g. through education (2001: 14-22). Maria Jarymowicz remains skeptical towards this problem; she proposes introducing the difference between group schemes (being the subject of modification) and group stereotypes (rigid and not being subjects of changes) (2001: 26-29), since stereotypes are long-lasting and durable.

Stereotypes are simple to confirm, although it is not easy to question them. Stereotypes seem to be unquestionable elements of the world's image (Stangor, Scheller, Macrae and Hewstone 1999: 122).

Stereotype is a kind of a ready formula allowing people to classify others, comparing them to themselves in order to construct their own image. Stereotypes are also an "instrument "to select knowledge and information concerning other groups. Stereotypes on sex refer to cultural definitions of femininity and masculinity as well as the roles and social expectations related to them. David Matsumoto and Linda Juang, in "Culture and Psychology", refer to the studies conducted by Williams and Best on gender stereotypes in 30 countries. Analyzing the studies conducted in 1982 and in the following years, they conclude that gender stereotypes are the most resistant ones. They refer to stereotypes concerning men as: active, strong, critical and mature, seeking autonomy, dominance and aggression. Stereotypes related to women present them as neurotic, passive, weak, caring and submissive, seeking help, care, affiliation and heterosexual contacts (2007: 233).

Sex stereotypes related to transsexual people form a specific trap. They offer a simple and explicit image of femininity or masculinity, but at the same time they insist that these people can establish borders for their own sex, being influenced by extreme sex stereotypes.

In the initial stage of collecting the material I mainly met transmen who, while discussing transsexuality, insisted that it is transwomen who face the biggest problems. They referred to a stereotypical image of a woman as a helpless and passive person who needs to take advice of other people. They demonstrated their image of being a woman but, on the other hand, they also, contrary to this image, gained a specific image of a man who is firm, active, strong etc. Their opinions concerning transwomen indirectly demonstrate how they perceive themselves as men. They define women as their direct opposite.

The essence of masculinity was a subject for discussion in internet forums for transgender people. It was started by a person being consulted by a psychiatrist before the transition process. In the comments there was no main, obvious definition of masculinity.

At first the response was obvious, but when I thought for a while, it turned out the matter was more complex than I thought. The biggest obstacle for me is that I don't understand women, what they think, what they feel, what they talk about it etc. I just feel I'm from another planet;) [...] I just see 
I've got more to do with my colleagues than with the women I know. I'm a stranger in the women's world, I feel I belong to the men's world, I feel good there (forum No. 1).

In this comment one witnesses the problem of what masculinity is. The attention is shifted towards the opposition between women and men. Masculinity is not understanding women, it is rather being like other men. Significantly, there is nothing related to defining oneself through the body. Yet, the significance of the body was emphasized by other forum users:

Another thing is body. Although I didn't begin the therapy, I don't see my body as a woman's body, I don't want anybody to see it like that. I think it's only hormones that can help, I'm afraid of hormones, but I think there's more to gain than to lose (forum No. 2).

However, the discussion focused on another thread associating maleness with power and dominance.

[...] for me, the one who has made endless efforts to be this stereotypical man, masculinity is power! I remember from my childhood that each of us wanted to be the one who's better, stronger, who's a leader, who's an alpha male. Testosterone makes you believe you are close to god, you'd better be careful! Well, not every man is an alpha male and most of men must be happy without it. Being emotional just meant being pissed or not. Being aggressive was obvious, I was aggressive to anyone not following my way. It wasn't about being aggressive physically, it was just my attitude to these people (forum No. 3).

I guess being a woman results from not being a man. I've always perceived myself, physically or mentally, as being a boy, as in my brain there is only one image: me as a man. I've felt like that since I was born, I don't really know why. Maybe it's immortal consciousness... (forum No. 4).

No men I know have been egocentric. Well, I'd say quite opposite. Ok, guys are more self-confident than women, they believe they can do everything, but in fact they do all to be more attractive to their beloved one. We've probably had it since prehistoric times, when a man had to be the one who hunts... if not, he would be prey! (forum No. 5).

I'd say I feel a man, as men are my idols, I want to look like a man, I want to be strong, I want to care for my woman and give her a sense of security, I want to give flowers to women, to give up my seat to a woman, I want other guys to invite me to a party with the men, I want to shake hands like a man, I want to have a muscled chest, my hobbies are typical for men, football, DIY, I don't understand other women, I'm not like them (forum No. 6).

Although the transsexual men quoted above referred to the complexity of being a man they focused on a man as a dominating, macho, responsible and bossy figure. Although in these words there is a train considering rejecting the body discourse or the patriarchal masculinity pattern, this discourse is still present while referring to male power, being a support to women, etc. What prevails is a traditional, stereotypical image of masculinity. It might stem from the fact it is a clear and pronounced image that could be essential to transsexual people if they are "tired" of existing between sexes. The hegemonic type Connell referred to, appears constantly in a peculiar manner; it seems that although several people focus on a softer depiction, the hegemonic type is still powerful. 


\section{MALE BODY}

Transsexuals are aware of social expectations related to their bodies that must correspond to their sex (it is emphasized in the APA and WHO diagnostic criteria I referred to in the introduction). This specific attitude towards body significance is strongly related to medical discourse concerning transsexuality. Transsexual people, before they undergo sex reassignment, depart the from social definition of their sex. Their gender identity does not correspond with their body: they are exposed to strong social pressure, since the society rejects the possibility of sex reassignment. When they make the decision for sex reassignment, they often try to dissociate from their past and from their previous body, following the rules of a binary sex system. It results from the need to protect themselves from being recognized as one who used to be another sex.

Patricia Gagné, Richard Tewksbury and Deanna McGaughey, who conducted studies related to the "coming out" process and constructing of identity by transgender people, emphasize the significance of the binary sex system (related to both sex and gender) to these people. The binary sex system, contrasting "male" and "female" categories and opposing one sex with the other, is a real challenge for transsexual people. Transsexual people have to overcome numerous obstacles at various levels of social life. In fact, nearly all interactions with other people force us to define ourselves as women or men. Transsexual people live under constant pressure to locate themselves in social reality in which either women or men are recognized. They cope with discomfort and hostility from other people unless other people are capable of locating them in socially accepted sex categories. According to Gagné, Tewksbury and McGaughey, this situation forces them to identify with the sex that corresponds better with them (1997: 504).

Transsexual bodily experience is unique because if there were not the body and its sex identity, there would not be an issue related to transsexual identity as it exists now. Being trapped in a wrong body is a fundamental issue related to transsexual identity. The relation between the body, its physical appearance, physical sex attributes and one's recognition as a man or a woman is particularly strong. The body is a serious problem and a challenge to transsexual people. Investigating this issue makes us realize how deep one's sex affects the way we move around public space. It reveals the fact there are numerous places where our position and presence depends on biological sex: temples, hospital rooms, classrooms, restrooms, beauty parlors, hair salons, etc. It could be problematic for a transsexual person to place themselves in a space with a clear division into "ladies" and "gentlemen" sections, being not only an instrument to maintain social order but also to preserve or demonstrate one's identity. One of the interviewed transsexual people (F to $\mathrm{M}$ ) describes his experience:

[...] when you enter social relations really serious problems begin. I mean school. Primary school. Girls here, boys there. I'll give you a simple example: my mum would take me to church. I was a religious kid. There were two divisions in the church, for girls and for boys. I liked the church, the celebrations, the incense smell, all these moments. But... there was a kind of grudge...it made me want to cry, I didn't know what it was. [...] I've realized it only recently. I returned to this church, this church of my childhood. I sat down on the left (the division for men - MB) I keep 
returning there now. I always sit down where I couldn't, the division which was not for me. Yes. And I feel fantastic. I feel good. Once I decided to sit down in women's sector. And I felt different. I felt uncomfortable. I didn't feel quiet (A. T f/m9).

This man recalls his childhood memories when he, as a girl, had to sit in the "women's section", the one with which he did not identify. He did not know what it was. Despite nice and pleasant memories of the church, what he remembers is "a certain grudge" connected with sitting in the "women's section", proving he was a girl, a woman.

For transsexual people, the body is an object of both love and hate. It is rarely something neutral, something that does not evoke extreme emotions. The way in which transsexual people perceive their body depends on the stage of transition and self-definition they are in.

Alicja Strzelecka stresses the importance of bipolar division of sexes for transsexual people. She insists that, according to the interviews she completed, transsexual people have to convince the experts about their identification with the sex not in accordance with their body in order to acquire all the certificates necessary for sex reassignment. In order to achieve this, they need to be convincing, which is why they often use stereotypical sex images.

One can say that, as a result of their traumatic experience, transsexual people support sex stereotypes, their coherence and explicitness as well as emphasize sex differences. Identifying their own place between male and female is a fundamental issue to them, a solution to their life dilemma. Following gender terminology, it might be said that a transsexual person must act their sex more accurately, more intensively, using all possible measures existing in their culture (Strzelecka 2004: 484).

Transmen are fully aware of what it means to be a man in their society. This knowledge is based on a stereotypical image of masculinity, both considering appearance and behavior. Internet forums for transsexual people is full of tips related to the most desirable image concerning the chosen sex. Portals for men recommend the following:

Don't wear a classic suit, unless you have to as a part of your job. [Normal] guys don't dress like that. Wearing a classic suit you won't blend in with the crowd. On the contrary, a cheap classic suit will prove your bad taste and it will make you look ridiculous. So, wear men's clothes but more casual and suitable to the situation. Don't brag about your masculinity, like: "look at the hair on my chest, arms, legs! A friend of mine told me I was the most masculine in the class; my girlfriend said I was her best lover!” It doesn’t sound smart (Mercory 2009).

The tips in the example are connected with clothing and behavior.

Suzanne Kessler and Wendy McKenna, when presenting transsexual people's everyday lives, notice that transsexual people before sex reassignment and those after presented a completely different attitude towards the body. These who had completed all the cycles of transition are not afraid that somebody could see their body anymore. However, they admit that transmen will always tend to use separate restrooms so that nobody would spot "something strange" about their body. People who are still waiting for sex reassignment procedure or even do not plan it, avoid all places where strangers could see their body (2000: 21-22). However, it seems difficult to agree with Kessler and McKenna here. In the interviews I often heard about the fear of being "discovered" by strangers. For transmen, a breakthrough stage 
of their transition is mastectomy, removing the breasts. The problem is that although they get a flat chest, there are scars left, which could be a giveaway to strangers.

For more than twenty years a slightly warmer temperature outside was a nightmare to him. He suffered agonies every hot summer. Well, he couldn't take off his clothes and the T-shirt didn't cover enough body. And even though the heatwave was killing him he'd rather burn in warm clothes. And the best he could do was stay at home. And now? He's expecting his first fine summer. He will leave home on a hot summer day and he'll enjoy it. He'll put on a T-shirt and feel the sun is also for him. God, what a relief! He looks at his new chest with both happiness and skepticism. He can do it. At last he looks at it, earlier it was covered. He saw himself, as a whole, uncovered after so many years. And he judges. There's necrosis on one nipple, something is festering. One side is not healing fine. The scars were to be smaller, the surgeon promised. And these deformations of the chest, nothing can be done about them. The scalpel did its job, that's all. He's like an insensitive judge of the whole healing process. He pitiably points out doctor's mistakes, concentrating on the details. As if it wasn't about his life. But he's happy about the operation. It's impossible not to be happy. Even if he was covered with scars he would still be happy (Lepiorz 2012).

This statement demonstrates transman's euphoria resulting from mastectomy, although this euphoria is slightly diminished due to the scars. The scars, however, can be reduced by plastic surgery, which are not available to all transsexual people as the cost can be prohibitive. It is money that blocks the achievement of body perfection. Obviously, this problem is not only related to transsexual people; body, however, is particularly significant to this group of people. Transsexuality is perceived from a different perspective by more affluent individuals. These who can afford plastic surgery procedures are capable of adjusting their body to their expectations. Less affluent people might experience their situation in a more frustrating way.

Another transman said, after a mastectomy procedure:

I've had it and I'm really happy. Other transmen will certainly envy my situation. I'll take off my T-shirt and nobody will see anything special. It's just a small scar around the nipple, not the big one across the whole chest. Several years ago the scars were even bigger, like a large anchor through the chest. We all know what an anchor looks like. Or like a big smile across your chest. I mean, a malicious smile (P. $\mathrm{t} / \mathrm{m})$.

This is a statement of a person who successfully had a mastectomy. He stresses the fact that the scars are not visible to other people, and compares himself to people who were not so lucky. This statement illustrates a less fortunate person's experience:

I didn't have it done properly, the upper part of my body, it was several years ago. I didn't feel good on the beach, I felt everyone's looking at me. [...] everyone told me "nobody's looking at you, come on, take it easy". I couldn't overcome this feeling for a long time, I thought everyone's going to guess, everybody will look at me in a way I don't want them to. It was a long time for me. I tried to have it corrected, in the end I got some tattoos made. I thought, if they keep staring at me, I will make them look at something else. It will be the tattoo they'll be interested in (D. T f/m).

The effects of the surgical procedure have led to profound disappointment and a fear of being recognized through the scars. The transman is obsessed with this fear, although he 
was told that nobody would recognize him, nobody would be really interested in the reason why he had the scars. However, he feels uncomfortable about it. That is why he decided to conceal the scars under the tattoos, which was in accordance with the macho image of a man: he can, or even ought to, have tattoos.

Apart from the problems of the scars resulting from mastectomy, transmen are concerned about the shape of their body, its musculature, and appropriate exercises for shaping it.

$\mathrm{F} / \mathrm{m}$ transsexuals are likely to look young. It is as if their body has just developed, grown. A transman doesn't look like a man in his thirties. You can't operate on an immature look. Lukasz wants to be "constructed" not only by surgeons, he wants to cooperate with them. He means his chest. He once told me everything was ok with his body, but its upper part wasn't big enough. It's typical for $\mathrm{f} / \mathrm{m}$ transsexuals. Their bottoms are too big for men. Too tiny shoulders. Adam's apple not masculine enough. Do "normal" guys care about their Adam's apple? Transmen care about everything. Everything must be right. Their hair must be man's style. Pink t-shirts are out of the question. This madness will go. Gradually you relax about being a man, you believe your maleness will remain with you even if you put on girls' clothes. You have no doubts about your maleness. Lukasz would like to have what "genetic" guys have. He will have it, but it takes time, it needs some effort. After all, making efforts is good for you; waiting shapes your personality, doesn't it? (Lepiorz 2012).

\section{HEGEMONIC MASCULINITY - CONCLUSION}

Katarzyna Wojnicka and Ewelina Ciaputa present the origin and development of studies on masculinity; they also define the sociology of masculinities (2011). The authors refer to Connell's masculinity models. Connell discusses hegemonic masculinity based on dominance, authority, cult of corporeality, work and heterosexuality. Other masculinities refer to the basic hegemonic one. Another type is complicit maleness, crossing the borders between hegemonic masculinity and feminine features; the third masculinity type - subordinate masculinity focuses on the behaviors antagonistic towards hegemonic masculinity, rejecting it. Connell published her paper in 1995 and today this publication, regarded as a classic, is frequently referred to in studies on masculinity. She proved that alongside the dominating masculinity model, in different cultures there are other, alternative models being created (Connell 2005).

In the case of transsexual people, image issues are particularly essential. It reflects the perception of their body as well as their attitude towards it. However, not only the issues related to image matter; the roles attributed to particular sex and their perception is a significant issue. There are certain differences to be noticed. Older people being interviewed emphasized the differences between two sexes, they needed to establish clear differences between what is male and what is female, whereas younger people tend to obliterate these differences, choosing unisex fashion to express themselves. A common strategy used among transsexual people before sex reassignment is seeking a particular transitional state expressing their real self so as not to be conspicuous but to express their true self, even in an illusionary way.

Although cultural and social differences between the sexes are diminishing, transsexuals believe these differences are fundamental. However, this blurred difference between male 
and female is advantageous for transsexual people during the transition period. Transwomen are more likely to use this strategy.

One transwomen recalls this "blurred" period:

It is difficult to say, as it's not just one solution, one situation. It's more like step by step. Make-up, stuff like that, I had it at home. But outside... in this blurred time... there were some attempts to... to wear make-up, but hoping nobody would notice it. Or let's say clothes...some delicate attempts to wear something more female-like, not being ostentatious, though... OK, trousers... more girlish but not to make people stare at me...And then, gradually... you know, when people knew, there was no need to disguise. I needn't do it. But it wasn't just one day when I changed my clothes and left. No, it's more gradual, more... step by step (DB, t m/f).

Feminine clothes and light make-up are signs of transforming oneself into a female, the stage when the fear of being recognized vanishes. These signs give a transwoman satisfaction and a sense of safety. An $\mathrm{m} / \mathrm{f}$ transsexual person who did not have a sex reassignment procedure due to their family situation stresses the importance of minor beauty procedures, like having long hair or manicured nails, helping them feel more feminine. For strangers, they might seem like just a neat and tidy man caring about his looks.

Transmen did not use unisex fashion willingly. They wanted to send a more unambiguous message relating to their sex, which they frequently based on a stereotypical image of a "real man", considering both clothes and behavior.

Both in free interviews and in forum statements masculinity was based on opposition in a binary sex system. What is not feminine is masculine, which could be the reason for the disdain for of unisex fashion. Referring to a macho-type approach (particularly in the forum statements) could prove the hypothesis I put forward in the introduction to the paper: that transsexual people focus on explicit, unquestionable images of masculinity, avoiding or not preferring transitional, blurred types.

Although gender performativity is more and more accentuated and queer theory is emphasized, I have the impression that transmen define themselves and shape their masculinity in a very traditional way, demonstrating an unfavorable attitude towards the sexually blurred image of androgynous men. The place where they live is undoubtedly a significant factor. It could be assumed that the transmen residing in large metropolitan areas will be more willing to cross gender borders and perceive men and women in a less stereotypical manner, whereas those coming from small homogenous communities will behave more conventionally.

Kessler and McKenna recognized the fact of the body no longer being problematic after the transition period. This standpoint cannot be explicitly accepted, as transsexual people tend to control their bodies, following the perfect body plan. While analyzing this body experience, a synopticon metaphor could be employed. The majority of transsexuals behave as if they, in every stage of the transition process, were controlled by the whole society. They are in the center, they are the ones who are observed by a normative majority. Transsexual people are constantly convinced that if anybody spotted any defect related to their body it would provoke inconvenient and embarrassing questions. Transsexual people's statements in Internet forums, things they recall from their past prove that they subject their bodies to constant control. Transsexual obsession to embody their identity properly within a common binary 
gender scheme ruins the flagship message of queer theory to reject this scheme. However, if one looks at it from another perspective, transsexuality is a certain clearance legitimating what queer theory strives for, demonstrating that a binary gender scheme is a social construct. Sex reassignment surgery, perceived as adjusting body and gender (traditional "treatment" for transsexuality) seems to be contradictory to poststructural concepts of queer theory. It strives for the embodiment into clear sexual identity, rejecting flexibility, fluidity, blur (Hines 2008: 109). Hines insists that the narration of a wrong body stems from medicalization transsexual people were exposed to, proving this narrative is the reason why the whole complexity of a transsexual identity is imperceptible. However, the studies on transsexuality mainly focus on body and sex. According to Julie L. Nagoshi and Stephanie Brzuzy, in social science body discourse focuses on the fact that body is an object in social processes. Yet, in their opinion transgenderism analyses demonstrate that the body is engaged in social relations more deeply and intricately. The body takes part in social activity through defining borders/ frames in interactions. Thus, they believe the body is not merely an object, as it generates social activity as well (2010: 435).

\section{REFERENCES}

Bancroft, John. 2011. Seksualność człowieka, Wrocław: Elsevier Urban \& Partner.

Bieńkowska, Małgorzata. 2012. Transseksualizm w Polsce. Wymiar indywidualny i społeczny przekraczania binarnego system płci, Białystok: Wydawnictwo Uniwersytetu w Białymstoku.

Bodnar, Adam. 2010. Wprowadzenie, in: Anna Śledzińska-Simon (ed.), Prawa osób transseksualnych. Rozwiqzania modelowe a sytuacja w Polsce, Kraków: Wolters Kluwer Polska, pp. 13-20.

Connell, R.W. 2005. Masculinities, Cambridge: Polity Press.

Dynarski, Wiktor, Anna Grodzka and Lalka Podobińska. 2010. Tożsamość ptciowa-zagadnienia medyczne, społeczne i prawne, in: Anna Śledzińska-Simon (ed.), Prawa osób transseksualnych. Rozwiazania modelowe a sytuacja w Polsce, Kraków: Wolters Kluwer Polska, pp. 21-38.

Gagné, Patricia, Richard Tewksbury Richard and Deanna McGaughey. 1997. Coming Out and Crossing Over. Identity Formation and Proclamation in a Transgender Community, "Gender and Society" 11, 4: 478-508.

Garfinkel, Harold. 2007. Studia z etnometodologii, Warszawa: PWN.

Foucault, Michel. 1993. Nadzorować i karać. Narodziny więzienia, Warszawa: Aletheia Spacja.

Hines, Sally. 2007. TransForming gender. Transgender practices of identity and intimacy and care, Bristol: The Policy Press.

Hines, Sally. 2008. (Tran)formacja gender: zmiana społeczna i transgenderowe obywatelstwo, in: Elżbieta H. Oleksy (ed.), Tożsamość i obywatelstwo w społeczeństwie wielokulturowym, Warszawa: PWN, pp. 99-120. 
Jarymowicz, Maria. 2001. W poszukiwaniu przesłanek sztywności stereotypów, in: Mirosława Kofta and Aleksandra Jasińska-Kania (eds), Stereotypy i uprzedzenia. Uwarunkowania psychologiczne i kulturowe, Warszawa: Wydawnictwo Naukowe Scholar, pp. 22-43.

Kessler, Suzanne J. and Wendy McKenna. 2000. Gender Construction in Everyday Life, "Feminism \& Psychology" 10, 1: 11-29.

Kofta, Mirosława and Aleksandra Jasińska-Kania. 2001. Wstęp. Czy możliwy jest dialog między społeczno-kulturowym a psychologicznym podejściem do stereotypów?, in: Mirosława Kofta and Aleksandra Jasińska-Kania (eds), Stereotypy i uprzedzenia. Uwarunkowania psychologiczne i kulturowe, Warszawa: Wydawnictwo Naukowe Scholar, pp. IX -XXIX.

Kurcz, Ida. 2001. Zmiana stereotypów, jej mechanizmy i granice, in: Mirosława Kofta and Aleksandra Jasińska-Kania (eds), Stereotypy i uprzedzenia. Uwarunkowania psychologiczne i kulturowe, Warszawa: Wydawnictwo Naukowe Scholar.

Lepiorz, Jakub. Płeć do zmiany. Ciag dalszy historii, www.wiadomości24.pl [09.01.2009].

Matusumoto, David and Linda Juang. 2007. Psychologia międzykulturowa, Gdańsk: Gdańskie Wydawnictwo Psychologiczne.

Merkury. 2009. Mistakes to be avoided, www.transseksualizm.pl [08.01.2009].

Nagoshi, Julie L. and Stephanie Brzuzy. 2010. Transgender Theory: Embodying Research and Practice, "Journal of Women and Social Work" 25, 4 [open access].

Stangor, Charles, Mark Scheller, Neil Macrae C. and Miles Hewstone. 1999. Stereotypy i uprzedzenia, Gdańsk: Gdańskie Wydawnictwo Psychologiczne.

Strzelecka, Alicja. 2004. Transseksualizm w procesie przekraczania barier, in: Alicja Kuczyńska and Elżbieta K. Dzikowska (eds), Zrozumieć płeć. Studia interdyscyplinarne II, Wrocław: Wydawnictwo Uniwersytetu Wrocławskiego, pp. 479-485.

West, Candance and Don H. Zimmerman. 1987. Doing Gender, "Gender \& Society" 1-2: $125-151$.

Wojnicka, Katarzyna and Ewelina Ciaputa. 2011. Wprowadzenie: refleksja naukowa nad spoteczno-kulturowymi fenomenami męskości, in: Katarzyna Wojnicka and Ewelina Ciaputa (eds), Karuzela z mężczyznami. Problematyka męskości w polskich badaniach społecznych, Kraków: Oficyna Wydawnicza Impuls, pp. 7-22.

\section{KONSTRUOWANIE MĘSKOŚCI TRANSSEKSUALNEJ W POLSCE}

Celem artykułu jest ukazanie sposobu, w jaki polscy transmężczyźni (osoby transseksualne identyfikujące się jako mężczyźni) będący w procesie tranzycji określają/konstruują męskość. Współcześnie tożsamość płci może być wyrażana w różny sposób. Na podstawie rezultatów własnych badań ukazuję, że transmężczyźni często odwołują się do tzw. stereotypowego wizerunku męskości. Ten typ męskości jest jasny i klarowny w odbiorze społecznym, nie budzi wątpliwości społeczeństwa co do czyjejś identyfikacji płci.

Słowa kluczowe: transgender/transseksualność, tożsamość indywidualna, tożsamość transmężczyzn, teoria queer 